\title{
Harmonia, Scientia, Economia - tři motivy západní filosofie výchovy Jan Hábl
}

DOI: $10.32725 /$ cetv.2021.033

\section{Abstrakt:}

Edukace je dynamická záležitost. Její pohyb souvisí s pohybem lidského myšlení. Jak člověk myslí, tak také jedná, a to i edukačně. V tomto eseji budeme didaktiku chápat jako disciplínu, která se táže „jak", a filozofii výchovy jako disciplínu, která se táže „proč“. Didaktika a její příbuzné disciplíny mají za úkol promýšlet metodologii utváření člověka. Filozofie výchovy nutí pedagogiku přemýšlet, proč dělá to, co dělá. Co je cílem. Co je smyslem. Zaměříme se na tři historické ideové pohyby, resp. metanarativní posuny, které určovaly (a určují) podobu současného filozofování o výchově. Smyslem tohoto exkurzu je nastínit historické a filozofické souvislosti za účelem porozumění naší současné pedagogické realitě tzv. západního světa. Budeme srovnávat ideová východiska doby pre-moderní, moderní a post-moderní a sledovat jejich edukační implikace. Cílem příspěvku je předložit argument ve prospěch celostního pojetí „educatio“, jak jej formuloval J. A. Komenský.

Klíčová slova: edukace, metanarace, filozofie výchovy

\section{Úvod: Otázky „proč“ ve výchově}

Edukace se podobá živé bytosti. V čase se mění, roste, hýbe, rozvíjí i chřadne. Jako u všech specificky lidských fenoménů je její dynamika závislá na pohybu lidského myšlení. Jak člověk myslí, tak také jedná, a to i edukačně. Chceme-li filozofovat o výchově, znamená to, že stojíme o lásku. Záleží nám na milování moudrosti (filo-sofia), v našem př́padě edukační - tedy nejen „jak“, ale též „proč“. V tomto eseji budeme didaktiku chápat jako disciplínu, která se táže „jak“, a filozofii výchovy jako disciplínu, která se táže „proč“. Didaktika a její přilehlé disciplíny mají za úkol promýšlet metodologii utváření člověka. Filozofie výchovy nutí pedagogiku přemýšlet, proč dělá to, co dělá. Co je cílem. Co je smyslem. Zaměříme se na tři historické ideové pohyby, resp. metanarativní posuny, které určovaly (a určují) podobu současného filozofování o výchově. Smyslem tohoto exkurzu je nastínit historické a filozofické souvislosti za účelem porozumění naší současné edukační situaci. Budeme srovnávat ideová východiska doby pre-moderní, moderní a post-moderní a sledovat jejich edukační implikace. Tj. budeme sledovat, jak se jednotlivé metanarativy promítaly do konkrétních edukačních filozofií. Záměrem tohoto eseje je předložit kombinaci antropologicko-ontologického a sociologického argumentu ve prospěch celostního pojetí „educatio“, jak jej formuloval J. A. Komenský. Na takto malém prostoru není možné vyhnout se 
zjednodušením, proto předem ohlašujeme záměr pouze črtat kontury, nikoli vykreslovat detaily. ${ }^{1}$ Hned v úvodu je třeba též předeslat, že se budeme zabývat souvislostmi pouze té části světa, kterou jsme si přivykli nazývat „západní“.

\section{Před dobou moderní: Harmonia - výchova jakožto umění}

Tušení před-zjednané harmonie mezi povahou přírody a povahou člověka (naturou a náturou) provází lidstvo odnepaměti. At už se jedná o písemnosti antické, nebo i starší mytopoetické zdroje, setkáváme se znovu a znovu s myšlenkou, že posláním člověka je úsilí o harmonii s veškerenstvem - fyzickým i metafyzickým. Nedostatek nebo porušení harmonie je univerzální zkušeností člověka. Lidé často jednají proti své vlastní přirozenosti i proti přirozenosti př́rody - ubližují sami sobě, ubližují druhým, ubližují přírodě. Různé kultury disponují různými etiologickými vysvětleními tohoto disharmonického stavu, ale shodují se v tom, že je třeba ztracenou (rajskou) harmonii jednak hledat a jednak o ni usilovat. ${ }^{2}$ Toto úsilí bývá ve výchovném pojmosloví nazýváno uměním. $\mathrm{V}$ čem toto umění spočívalo? Pro explikaci této otázky nám poslouží filozoficko -výchovný systém Jana Amose Komenského. Komenský patř́i k posledním velkým architektům edukační harmonizace před nástupem moderního paradigmatu. Jeho projekt „nápravy věcí lidských“ je pro účel tohoto exkurzu více než príhodný, poněvadž svým metafyzickým zakotvením perfektně demonstruje kontrast mezi pre-moderním a moderním pojetím filozofie výchovy. ${ }^{3}$ Vynikající ukázkou, jak blízko i daleko měl Komenský k světu modernímu, je výsledek jeho proslulého setkání s René Descartem, otcem moderního způsobu myšlení. Z Komenského autobiografických zápiskủ víme, že se s Descartem setkal roku 1642 na své cestě z Anglie. Komenský byl v té době již významnou osobností evropského formátu. Rovněž jeho mladší kolega byl znám mezi učenci především pro své převratné rozpravy o vědecké metodě, která by měla jednou provždy poskytnout badatelům neochvějnou jistotu poznání. Když se po čtyřhodinovém rozhovoru rozešli, bylo to sice $\mathrm{v}$ přátelském duchu, ale $\mathrm{v}$ zásadním nesouhlasu. Jejich spor symbolizuje i vystihuje podstatu rozdílu mezi pre-moderním a moderním myšlením. „U mne jen část, čeho u tebe celek“, vzpomíná Komenský na Descartova slova, kterými prý uzavřel epistemologickou rozpravu o věrohodných zdrojích poznání. ${ }^{4}$ Descartova metodická pochybnost byla pro Komenského nemyslitelná. Distancovala člověka od světa jako nedělitelného celku a redukovala lidské poznání pouze na rozum. Proč takový redukcionismus, když jsou člověku dány i další zdroje poznání, polemizuje Komenský. Konkrétně jmenuje tři „knihy“, v kterých člověk smí čist, aby se dozvěděl vše potřebné $k$ dobrému životu: kosmos (svět), mikrokosmos (člověk) a zjevení (Písmo). Každá kniha vypráví o tomtéž po svém, vzájemně se doplňují. Zásadní je zde idea celistvé harmonie, kterou Komenský nechápe jako nahodilý př́davek k povaze jsoucna, ale jako „transcendentální atribut, bez něhož nic jsoucího nemůže být'. ${ }^{\text {‘ }} \mathrm{Za}$ předpokladu, že celý vesmír je harmonickým celkem spočívajícím na jednotných principech, pak věci, které nelze poznat přímo (rozumem či indukcí), mohou být odvozeny z jiných zdrojů. Což

1 Pro hlubší studie této oblasti doporučuji např. Martin STROUHAL, Teorie výchovy. K vybraným problémům a perspektivám jedné pedagogické disciplíny, Praha: Grada, 2013; Jitka LORENZOVÁ, Kontexty vzdělávání v postmoderní situaci, Praha: Humanitas, 2016; Jan HÂBL, Ultimate human goals in Comenius and modern Czech pedagogy, Hradec Králové: Gaudeamus, 2011; Jan HÁBL, On being human(e). Comenius Pedagogical Humanization as Anthropological Problem, Eugene, Oregon (USA): Pickwick Publications (Wipf \& Stock), 2017; Jiř́ POSPÍŠIL, Filosofická východiska cíli výchovy a vzdělávání v období novověkého obratu, Olomouc: Hanex, 2009.

2 Srov. Francis August SCHAEFFER, How Should We Then Live? The Rise and Decline of Western Thought and Culture, London: Marshall Morgan \& Scott, 1980.

3 Daniel MURPHY, Comenius: A Critical Reassessment of His Life and Work, Dublin: Irish Academic Press, 1995.

4 Na rozhovor s Descartem vzpomíná Komenský ve své apologetické autobiografii, kterou napsal na sklonku života. Pro více detailů viz Amadeo MOLNÁR - Noemi REJCHRTOVÁ, J. A. Komenský o sobě, Praha: Odeon, 1987, s. 155-156.

5 Radim PALOUŠ, Komenského Boží Svět, Praha: Státní pedagogické nakladatelství, 1992, s. 24. 
je přesně to, co Komenský činí jak ve své vševýchově (pampaedii), tak ve své všemoudrosti (pansofii). Uvádí paralelní zdroje do vzájemné souvislosti, harmonizuje svět(y). Nalezne-li v jednom světě (př́rodě) edukativní či emendační (napravitelský) potenciál, modo analogico (cestou analogie) z něj vytěží maximum pro svět lidský. Nebot’ „co je v prŕírodě napsáno velkými písmeny, je zapsáno v člověku malými“, parafrázují Komenského Darling a Nordembo. ${ }^{6}$

Jak se tyto kosmologické předpoklady promítají do pojetí výchovy? Již v úvodní části Velké didaktiky ${ }^{7}$ vyslovuje zásadní tezi, že „vše, co jest, jest k něčemu“ ${ }^{8}$ Coby filozof nahlíží Komenský přirozené jsoucno „sub specie educationis“9 , aby v jeho povaze objevil výchovný potenciál. Jinými slovy - přirozený svět není náhodný výskyt věcí či sled událostí, které se bezesmyslně odehrávají a uplývají odnikud nikam, nýbrž účelným pobytem existencí povolaných ke smyslu. Vše, co jest, je „aby“, jak vykládá R. Palouš. ${ }^{10}$ Vše je za nějakým účelem, pro něco, k něčemu. Každá věc, každé jsoucno je charakteristické svou teleologickou povahou. Má cíl ležící mimo sebe, překračuje samo sebe, existuje, tedy vy-stupuje ze sebe, nebot tak bylo zamýšleno a stvořeno. Řečeno Komenského pojmoslovím, nic není „samosvojné“, tedy existující samo pro sebe. ${ }^{11}$ A právě v tomto božském vkladu spočívá edukační nadání přirozeného světa. Zrozením člověk vstupuje do školy světa, která ze své přirozené podstaty vychovává člověka k pravé podstatě lidskosti. Příroda sama skýtá didaktický materiál, jen je potřeba přirozený svět pozorně sledovat.

Tak například si Komenský v jednom ze svých fundamentů ${ }^{12}$ všímá, že příroda „nečiní skoků, ale kráčí ku předu postupně“, což demonstruje na příkladu růstu ptáčat. Když se ptáče narodí, „neporučí mu starý pták hned létati a hledati pastvy“, říká Komenský a pokračuje: „A když se opeří, nežene ho hned zase z hnízda, aby létalo, nýbrž cvičí je znenáhla, nejprve v samém hnízdě roztahovati křídla, potom nad hnízdem pozdvihovati a jimi pohybovati, pak mimo hnízdo, avšak přece na blízku zkoušeti let, pak s větve na větev, potom se stromu na strom, s hory na horu přeletovati; a tak se stává, že konečně je bezpečně svěří širému vzduchu. “ Z čehož Komenský analogicky vyvozuje následující didaktické zákonitosti:

1. Souhrn všeho učení budiž rozdělen přesně na třídy, aby to, co je napřed, všude razilo cestu a rozžehalo pochodně tomu, co jest za tím.

2. Čas budiž rozdělen pečlivě, aby každému roku, měsíci, dni a hodině připadl jeho vlastní úkol.

3. Toto rozměření času i práce budiž zachováváno přesně, a nic nebudiž vynecháváno, nic převraceno.

Podobně dedukuje Komenský množství dalších principů, přičemž společným motivem je vždy

6 John DARLING - Sven Erik NORDEMBO, Progressivism, in: The Blackwell Guide to Philosophy of Education, Blackwell, 2003, s. 291.

7 Je třeba vyslovit, že Komenského užití pojmu „didaktika“ je jiné než to současné. Komenský nechápe didaktiku jako metodologický návod, jak učit konkrétním předmětům. Jeho didaktika je filozofií výchovy v pravém slova smyslu - pojednává ontologické i teleologické určení člověka a vyvozuje principy lidské vzdělavatelnosti.

8 Celé znění dotčeného citátu zní takto: „Rozumíme také slovem přirozenosti všeobecnou prozřetelnost Boží čili proud božské dobroty, která neustává konati při všech všecko; totiž při jednom každém stvoření to, k čemu je určila. Nebot známkou božské moudrosti bylo, že nic nečinila nadarmo, tj., ani bez nějakého cíle, ani bez prostředkův, určených k dosažení onoho cíle. Cokoliv tedy jest, jest k něčemu; a aby to tam mohlo dospěti, opatřeno jest jistými potřebnými ústroji a pomůckami, by dokonce i jakýmsi pudem, aby nic nebylo vedeno k svému cíli proti své vůli a s odporem, nýbrž spíše lehce a př́ijemně s popudem samé přirozenosti.“Jan Amos KOMENSKÝ, Didaktika velká, Praha, 1905, s. 51-52.

9 Srov. Jan PATOČKA, Komeniologické studie II, Praha: OIKOYMENH, 1998, s. 133.

10 Srov. Radim PALOUŠ, Čas výchovy, Praha: Státní pedagogické nakladatelství, 1991.

11 O samosvojnosti Komenský mluví často. Viz např. Komenského raný spis Centrum securitatis (Hlubina bezpečnosti) nebo pozdní Unum necessarium (Jedno potřebné).

12 Jedná se o fundament č. VII v Didaktice velké, ze kterého cituji veškeré následující úryvky. Viz KOMENSKÝ, Didaktika velká..., s. 155n. 
harmonický soulad didaktické metody s apriorní povahou přirozenosti světa. Zde dle Komenského spočívá hlavní neřest tehdejších škol: nedávají se vést přirozeností světa a věcí samých, namísto toho jsou neprrirozenou "mučírnou hochü“. ${ }^{13}$

Člověk však nutně potřebuje vzdělání, které by harmonizovalo jeho přirozenost $s$ přirozeností světa. Z celého tvorstva je totiž člověk jedinou bytostí, která je schopna sama ze sebe udělat konečný cíl své existence, učinit se „homo mensura“ čili „samosvojným“, což na rozdíl od antiky či moderny není vnímáno jako pozitivum, ale jako jádro lidské tragédie, ve kterém Komenský spatřuuje př́ičinu všech lidských „změteností, „motanin“ a „jinudostí ${ }^{\text {“14. }}$. Coby samosvojný člověk rušivě vyčnívá z řádu stvoření či panharmonie veškerenstva (jak by řekl „pozdni' Komenský), nebot samosvojnost je pro celé tvorstvo nepřirozená, nepůvodní a ne-řádná. Nejenže odtrhuje člověka od Boha, z něhož plyne veškeré „dýchání i život sám“, ale též odděluje lidi od lidí, poněvadž „působí, aby člověk samého sebe za cíl stavěl, to jest samého sebe miloval, samému sobě přál, o samého sebe se staral“. ${ }^{15}$

Jak si Komenský tuto specificky lidskou tendenci vysvětluje? Hned v Provolání, tj. v úvodu své Velké didaktiky, poměrně obšírně vykládá stav i př́íiny lidského problému, na který hodlá následně svou didaktikou odpovědět. Vychází z tradiční biblické narace, kde je člověk představen jako „Imago Dei“, tedy jako bytost stvořená pro bytostný vztah s Bohem. „Hle, člověk tedy není v sobě samém v pravdě ničím jiným než harmonií!“"16, konstatuje Komenský. Avšak důsledkem archetypálního pádu lidství, způsobeným lidskou touhou po bohorovnosti, člověk ztratil tzv. „nexus hypostaticus", tedy hluboký osobní vztah se svým Stvořitelem. Coby bohorovný se člověk uzavřel či „zakřivil“ do sebe, čímž se odcizil své přirozené pre-ordinované instanci umožňuící tolik důležitou transcedenci. Důsledkem tohoto pokřivení není schopen naplnit své bytostné lidské poslání. Ale lidství není nadobro ztraceno, pokračuje Komenský: „Proto jako o hodinách nebo hudebním nástroji, jejž vytvořily ruce zkušeného umělce, jsou-li pokaženy a rozladěny, neříkáme hned, že již nejsou k potřebě [...] tak i o člověku, třeba je pokažen pádem hříchu, je stanoviti, že božskou mocí může jistými prostředky býti uveden znovu v souzvuk “. ${ }^{17}$

Za povšimnutí stojí, jak realisticky a komplexně je zde vystižena dis-harmonická povaha lidství: Komenský ví, že člověk je nadán jak pozitivním, tak negativním potenciálem. Lidskost lidí není v porádku, ale není ani docela ztracena. Lidská podstata není předem dána tak, jako je např. dána dýni její dýňovitost nebo trojúhelníku jeho trojúhelníkovitost. Trojúhelník se svou trojúhelníkovitostí nemůže nic udělat, nemůže se stát trojúhelníkovitějším, nebo se naopak zvrhnout v cosi netrojúhelníkovitého. Avšak člověk ano. Člověk je schopen lidskosti i nelidskosti. Každý lidský potenciál, každý poznatek či dovednost (třeba i školsky nabyté) mohou mít jak pozitivní, tak negativní aktualizaci. Mohou být použity $\mathrm{k}$ dobrému, ale i ke zlému. Dokonce čím větší potenciál, tím větší nebezpečí, nebot " corruptio optimi pessima “18. Proto je dle Komenského třeba „dílny lidskosti“, školy či výchovy, jejímž prvořadým úkolem bude kultivace negativních sklonů lidského potenciálu. Slovy Komenského spočívá veškerá výchova v překonávání „samosvojné“ tendence, tj. ve vy-vádění (e-ducatio) z hříšné soběstřednosti či uzavřenosti. Komenský objasňuje smysl svého pedagogického projektu v pozdním všenápravném díle, kde říká, že vzdělání je žádoucí proto, „aby žádný člověk neupadal v nečlověka “19.

13 Jan A. KOMENSKÝ, Didaktika velká: X, 7.

14 Pojmosloví, které Komenský ve svých dílech nejednou opakuje. Pro nejranější zmínky viz např. Jan Amos KOMENSKÝ, Hlubina bezpečnosti, Praha, 1927.

15 Srov. Zdeněk KOŽMíN - Drahomíra KOŽMíNOVÁ, Zvětšeniny z Komenského, Brno: Host, 2007.

16 Jan A. KOMENSKÝ, Didaktika velká: V, 17.

17 Tamtéž.

18 „Nejhorší jest, když se pokazí nejlepší.“

19 Jan Amos KOMENSKÝ, Obecná porada o nápravě věcí lidských, Praha: Academia, 1992, s. 788. 
Takto pojatá edukace již ze své podstaty implikuje ascendenci lidskosti čili vzestupný pohyb, což je pohyb velmi žádoucí, nebot uvádí člověka do kýženého transcendentního, tj. sebe-překračujícího procesu. V praxi to znamená, že se člověk učí jednat, rozhodovat a zodpovídat nejen s ohledem na sebe samotného. Je veden k rozpoznání, že v řádu bytí je podřízen instanci, která ho bytostně přesahuje. Zde lze též spatřovat základ Komenského tolik ceněného univerzalismu či holismu $s$ velmi významnými sociálně-etickými důsledky. ${ }^{20}$ Kultivaci či nápravu lidskosti Komenský totiž nezamýšlí pouze ve smyslu individuálním, ale celostním, globálním, jak naznačuje předpona pan, kterou ve vrcholném stadiu svého díla předřazuje každému lidskému úsilí. Harmonické vztahování (smíření, eiréné) $\mathrm{k}$ instanci poslední implikuje harmonické vztahy $\mathrm{k}$ druhým lidem a tím i k celému tvorstvu. ${ }^{21}$ Komenskému neleží na srdci pouhá dílčí jsoucna, ale celé bytí. V jeho škole tedy nepůjde jen o zlidštění individua, ale o „nápravu věcí lidských“, poněvadž Komenský ví, že blaho jedince nemůže být dosaženo bez blaha celku, jak naznačuje jeho slavný výrok: „Všichni na jednom jevišti velikého světa stojíme, a cokoliv se tu koná, všech se týče "22.

Je evidentní, že Komenského výchovně-vzdělávací systém v žádném případě nesnese přívlastek „vědecký“. Přestože se v Komenského době již hovořilo o „vědách“, Komenský sám nazývá svou pedagogiku tradičním ars, tj. uměním, nikoli však v estetickém slova smyslu. Jde o umění, jehož podstatu Komenský vyjádřil svým slavným mottem na titulní straně souboru Opera didactica omnia: Omnia sponte fluant, absit violentia rebus. ${ }^{23}$

\section{Modernita: Scientia - edukace jakožto věda}

Modernímu uchu zní Komenského syntéza kosmologických premis, antropologických maxim a didaktických dedukcí jako čirá alchymie. Když se rodil moderní př́běh, sloganem osvícenců bylo sapere aude, tedy člověče, „důvěřuj svému rozumu!“ Šlo o reakci na středověkou tradici spoléhání se na vnější autority - viz Komenského Písmo, Stvořitel apod. Osvícenství chápalo samo sebe jako věk dospívání humanity, jako velký dějinný okamžik, kdy lidstvo konečně sebralo odvahu k osvobození se ze spárů spekulace a nevědomosti, přičemž nástrojem emancipace se stalo nově objevené lidské ratio, pomocí kterého člověk doufal „odhalit, popsat a vysvětlit veškerý přirozený řád věcí ${ }^{\text {“24. }}$ Z počátku vše vypadalo velmi nadějně. Vybaveni Descartovými a Baconovými metodickými pokyny, odhalují první badatelé nesmírné množství nových faktů, jevů či zákonitostí ohledně našeho přirozeného světa. Poznatky se kumulují a exponenciálně množí, vzniká potřeba je utřídit, zpřehlednit, pojmenovat, zaznamenat, verifikovat, interpretovat, vymezit apod. Objevují se první „logie“ ${ }^{25}$ neboli vědy v moderním slova smyslu - zoologie, geologie, filologie, etnologie, psychologie a nespočet dalších. Každá vědní disciplína disponuje vlastní terminologií a vnitřní strukturou, vlastním specifickým předmětem bádání a vlastním souborem badatelských prostředků (nejen experimentem). At̉ už se jednalo o vědy př́rodní nebo humanitní, společným jmenovatelem bylo několik základních znaků:

20 Srov. Patočkovo pojednání univerzalismu u Komenského, Jan PATOČKA, Komeniologické studie III, Praha: OIKOYMENH, 2003, s. 190n.

21 Srov. David Ian SMITH, „It would be good to have a Paradise.“ Comenius on learners past and present, in Restoration of human affairs. Utopism or realism?, ed. Jan HÁBL, Oregon: Cascade Books, 2021, s. 29n.

22 Jedná se o parafrázi z Unum necessarium: „Všichni sedíme ve velkém divadle světa: cokoli se zde děje, dotýká se všech.“ Český překlad převzat z Amadeo MOLNÁR, J. A. Komenský..., s. 294. Pro více podrobností k otázce Komenského pedagogiky viz Jan HÁBL, Lekce $z$ lidskosti v životě a díle J. A. Komenského, Praha: Návrat, 2011.

23 „Nechť vše plyne přirozeně a bez násilného působení." Viz také Jan A. KOMENSKÝ, Didaktika analytická, Praha, 1946, s. 42.

24 Andrew WRIGHT, Religion, Education and Postmodernity, London: Routledge Falmer, 2004, s. 1.

25 Řecké logos znamená slovo nebo také pojem, smysl, rozumění, vědění. 
1. Důraz na objektivitu. Právě v důsledku badatelských pokynů prvních metodiků vědy, jako byli R. Descartes nebo F. Bacon, se imperativem vědy stalo úsilí o objektivní poznání. Pravdivost nesmí být určována autoritou, tj. mocí, at už úřední, církevní nebo jakoukoli jinou. Objektivní poznání skutečnosti pochopitelně vyžaduje distanci od poznávaného. Má-li badatel poznat, jak se věci skutečně mají, tj. an sich, jak říkával Immanuel Kant, subjektivní pocity, potřeby či zájmy jednak nemají a jednak nesmí mít vliv na předmět bádání. $V$ raném období modernity byla tato noetická distance vnímána neproblematicky. Badatel karteziánského typu jednoduše předpokládá, že při svém zkoumání dokáže zajistit neutralitu, tj. aby ani on sám (res cognitas), ani žádný jiný faktor neovlivňoval poznávanou skutečnost (res extensa). Limity tohoto předpokladu byly rozpoznány až v pozdním stadiu modernity. ${ }^{26}$

Pro úplnost je třeba zmínit, že modernisté si byli vědomi problému ne-spolehlivosti smyslového poznání. Mluvil o tom již zmíněný R. Descartes, ale nejhlasitěji na tento problém upozornil David Hume, představitel skeptického kř́ídla empirické filozofie. Proti Humovi postavili tzv. logičtí pozitivisté princip verifikace, který požaduje, aby každý pravdivostní výrok byl v posledku testován právě smyslovou zkušeností. Tento trend se na nějaký čas ve vědeckých kruzích ujal (a stále ujímá), ovšem má opět své badatelské hranice, poněvadž redukuje veškerý morální, estetický či religiózní diskurz na úroveň emotivněsubjektivních výpovědí, nemajících žádný kognitivní vztah k reálnému světu. A to proto, že na bázi smyslové není nijak možné verifikovat, zda nějaká bytost je „dobrá“, západ slunce „krásný“ nebo pravda „svatá“. Navíc princip smyslové verifikace trpí tzv. auto-referenční inkoherencí, poněvadž jej samotný nelze nijak smyslově ověřit. ${ }^{27}$

2. Autonomie. Jak již napovídá etymologie pojmu auto-nomos (vlastní-zákon), chápe moderní myslitel sám sebe, resp. vlastní rozum, vlastní pozorování apod. jako tu instanci, která rozhoduje o pravdivosti či nepravdivosti jakékoli teze či zákonitosti. Již žádný kněz, král či feudál nebude rozhodovat o tom, co je pravda a co nikoliv. Vědec disponující světlem rozumu nepotřebuje tyto vnější autority, umí na to přiijít sám s pomocí svých vědeckých nástrojů. Osvícenecká revolta vưči tradičním autoritám je pochopitelná. Scholastická pokladnice moudrosti starých otců byla sice $\mathrm{v}$ mnohém krásná, filozoficky hluboká a podnětná, ale také plná omylů, bludů a pochybných spekulací. Čím dogmatičtěji střežil scholastikus svou sumu milovaných, tradovaných, po otcích zděděných a léty prověřených doktrín, tím více se vyostřoval spor s vědcem, který pomocí empirie a indukce objevoval zcela odlišný svět. ${ }^{28}$ Dobře to ilustruje epizoda ze 17. století, kterou připomíná František Drtina ve svém Úvodu do filosofie: jistý jezuitský provinciál chtěl přesvědčit svého kněze o některých skutečnostech vesmíru, a proto jej vybídl, aby se podíval dalekohledem na sluneční skvrny. Na to kněz odpovídá: „K čemu to, synu můj? Dvakrát jsem Aristotela přečetl a nic takového jsem tam nenašel. Skvrny ty neexistují, nýbrž jsou jen chybou bud' tvého zraku, nebo tvých skel. ${ }^{\text {‘29 }}$

Důraz na autonomii lidského rozumu lze pozorovat i v dalších oblastech společenského života. Ve Francii byl např́íklad 22. záŕí roku 1792 zrušen tradiční kalendář a rok 1793 byl prohlášen za rok Jedna. Sedmidenní týden byl prodloužen na deset dní. Důvod je nasnadě. Byly to právě vnější autority, které zavedly dosavadní rád věcí i vnímání času. Letopočet

26 Srov. Stenley James GRENZ, Primer on postmodernism, Grand Rapids: Eardmans, 1996.

27 Srov. Stephen TOULMIN, Cosmopolis, The Hidden Agenda of Modernity, Chicago: University of Chicago Press, 1990.

28 Srov. Arthur VAN DOREN, History of Knowledge, New York: Random House Publishing Group, 1991.

29 František DRTINA, Úvod do filosofie, sv. I., Praha, 1914, s. 558. 
se tradičně počítal od události, která byla považována za historicky nejvýznamnější, tj. od narození Ježíše Krista, spasitele lidstva. Rovněž týdenní uspořádání se odvíjelo od biblického výroku „šest dní budeš pracovat a sedmý den odpočineš“. Osvíceneckému člověku však žádná autorita nebude diktovat, co má nebo nemá dodržovat. Jakožto autonomní si zařídí svůj život po svém.

3. Optimismus. Povzbuzen úspěchy na poli vědním, nabývá moderní myslitel přesvědčení jistoty pokroku na poli morálním či obecně lidském. Dobře to vyjádřil Stanley Grenz: „Moderní vědec považuje za axiomatické, že to, co poznání zjistí, je vždy dobré. Tento předpoklad interní dobroty poznání činil osvícenecký pohled na svět optimistickým. Vedl $\mathrm{k}$ víře, že pokrok je nevyhnutelný, že věda nás spolu se silou vzdělání nakonec zbaví vší bezbrannosti vůči přírodě a také veškerého společenského otroctví“30. Jinými slovy - ten, kdo „správně“ ví, bude též „správně“ jednat. Otázka spojení mezi scientia a conscientia nebyla sama o sobě nijak nová, avšak předpoklad, že věda a vzdělání budou automatickým humanizačním faktorem v procesu zušlechtování lidskosti, dostal svou doktrinální podobu teprve $\mathrm{v}$ rámci moderního příběhu. ${ }^{31}$ Moderní člověk věřil, že pokrok lidstva směrem k lepším zítřkům je jistý a že je jen otázkou času, kdy díky nezadržitelnému rozmachu poznání budeme schopni ovládnout přírodní svět, dokonce „poručit i větru a dešti“, až nakonec dosáhneme kýženého ráje na zemi.

Optimistického ducha doby vynikajícím způsobem vyjadřují vznosná zvolání historika Jana Klecandy v jeho přehledovém kompendiu shrnujícím veškeré události 19. století. Jedná se o závěrečná slova. Přestože je to především hold národním buditelům, nemůžeme neslyšet echo doby:

„Pohlédneme-li na stav národa našeho při počátku století devatenáctého, povážíme-li, že my v mnohém musili jsme teprve pracně vybudovávati základy, jež jiným štastnějším národům byly již dány, že bez jakékoli podpory, ano často $s$ překážkami nám v cestu stavěnými musili raziti cesty našemu českému pokroku, seznáme, že čím dnes jsme, stali jsme se vlastní silou, ne z milosti mocnějších činitelů, již by byli nad námi drželi příznivou ruku, nýbrž namnoze jim navzdor, přes jejich nepřátelské úsilí a neprrízeň. A toto úsilí, jež získali jsme pohledem do minulosti, dodává nám nezlomné, v sebedůvěře kotvící síly pro všecky boje příští. Odvracejíce se potěšeni od století devatenáctého, jež národu našemu přineslo obrození, pohlížíme jasným zrakem vstříc století dvacátému. Snad nové boje, jistě však nová práce nás očekává. Nelekáme se těch bojů, jsouce si vědomi své síly i toho, že národ, jenž zná svá práva a dovede pro ně a za ně bojovati, trpěti i oběti přinášeti, konečně musí zvítěziti. Těšíme se na tu práci, vědouce, že naše síly, naše schopnosti i naše láska, pojistí nám naše místo mezi národy. Zavíráme knihu dějin věku devatenáctého a pozdravujeme století nové, v němž bohdá i našemu národu kyne štastná a slavná budoucnost. “32

V rámci moderního paradigmatu měla škola nezastupitelnou roli. Byla klíčovým prostředkem ke sdílení optimisticko-racionalistického metapř́běhu. Veškeré didaktické nástroje, vědomosti, fakta, dovednosti či hodnoty, kterými disponovala, které pěstovala, rozvíjela a předávala, měly svůj význam právě v procesu realizace moderní agendy. A nutno dodat, že v tom byla velmi úspěšná. Díky

30 GRENZ, A Primer on postmodernism..., s. 4.

31 Srov. Peter MENCK, The formation of conscience: a lost topic of Didaktik, in: Curriculum studies, vol. 33, III, 2001 , s. 261-275.

32 Jan KLECANDA, Devatenácté století, Praha: Josef Richard Vilímek, 1915, s. 888. 
moderním empirickým vědám se vybavila takovým arzenálem, o jakém se starým vzdělavatelům, jako byl W. Ratke, E. Bodin, Komenský nebo J. F. Herbart, ani nesnilo. Jasně se vyprofiloval předmět pedagogiky, do široka se rozvětvil pedagogický výzkum, systematizoval se soubor základních a pomocných pedagogických disciplín a v neposlední řadě (v důsledku vědeckého bádání) se nebývalým způsobem rozvinula vlastní metodologie vyučování. Moderní pedagog tak disponuje velmi komplexním repertoárem tradičních i alternativních strategií $\mathrm{k}$ předávání poznatků i kompetencí, přičemž konečným cílem veškerého pedagogického úsilí je takzvaně „připravit jedince pro život“, což dekonstruováno pozdější post-moderní hermeneutikou znamená zformovat jej tak, aby byl schopen přijmout a dobře odehrát svou společensky určenou roli v rámci moderního scénáře ${ }^{33}$ Že se často jednalo o více či méně latentní indoktrinaci, vyplývá již ze samotné povahy př́běhu. Faktem ale zůstává, že to byla indoktrinace velmi funkční. Po celá staletí účinně produkovala a upevňovala takřka religiózní víru v pokrok. ${ }^{34}$ Zastřešena takovou metanarací, patřila academia $\mathrm{k}$ věcem „posvátným“, nebot byla klíčovým místem, v němž se tvořily a rozvíjely hodnoty sloužící společenské integraci. Důstojnost učitelského taláru pak spočívala $\mathrm{v}$ dědictví historické kontinuity, poněvadž škola moderní, jakkoliv vymezena viči škole pre-moderní, přece jen pokračovala v tradici houževnatého a obezřetného hledání, zachovávání a předávání pravd, které byly ve své mnohosti skládány do velkého jednotícího celku - jak naznačuje již samotný pojem uni-versity.

\section{Postmodernita: Economia - pedagogika jakožto nástroj trhu}

V průběhu 20. století se naděje moderně konstruovaného světa začaly pomalu rozpadat. Ukázalo se, že i když vědění přináší lidstvu nebývalé technické možnosti, samo o sobě nedokáže zajistit lidskost a morální vytrríbenost. Je jistě pravda, že ten, kdo ví, má moc, jak postřehl už F. Bacon. ${ }^{35}$ Rovněž je nesporné, že $k$ vědění je třeba vést, tj. vzdělávat. Historická zkušenost však odhalila, že vědění a vzdělání může být užito $k$ dobrému, stejně jako ke zlému. Pokud si připomeneme zrůdnosti 20. století, na nichž se věda aktivně podílela, bude nám automatický humanizační předpoklad doby moderní připadat směšně a možná trestuhodně naivní. Dnešní člověk, místo aby se vděčně oddával péči vědců, má spíše sklon pozorně sledovat jejich snažení se stále větším podezřením a obavami. Kdo ví, k čemu by mohl být jejich vědo-technický výdobytek zase zneužit. ${ }^{36}$ Navíc mimořádný rozvoj technologií a věd, který západní společnosti skýtá nebývalou moc a blahobyt, produkuje množství problémů, které přerůstají do globálních rozměrů a se kterými si neví rady. Kultura nadbytku a prosperity ostře kontrastuje se skutečností bídy milionů hladovějících, strádajících, negramotných či marginalizovaných jedinců i celých národů, kterým „civilizovaný“ svět neumí pomoci, nebot má dost problémů sám se sebou. Frommovsky řečeno, navzdory vědo-technické přesycenosti je lidsky „podvyživený“. Jeho vyspělá technokracie generuje řadu antihumánních projevů jako zvěcňování člověka, odcizující individualizaci či odosobňování mezilidských vztahů. Namísto kýženého ráje na zemi upozorňují sociologové na realitu dramatického úbytku morální gramotnosti, propadu sociálního kapitálu (člověk nevěří člověku), hrozeb globální sebedestrukce, střetů civilizací, různých forem extremismů apod. Člověk jako lidská osoba je dokonce považován za „ohrožený druh" ${ }^{\text {“37 }}$.

33 Srov. Stephen TOULMIN, Cosmopolis, The Hidden Agenda of Modernity, Chicago: University of Chicago Press, 1990.

34 Srov. Elmer John THIESSEN, Teaching for Commitment, Liberal Education, Indoctrination and Christian Nurture, McGillQueen's University Press, 1993; Jan HÁBL, On being human(e). Comenius Pedagogical Humanization as Anthropological problem, Eugene, Oregon (USA): Pickwick Publications (Wipf \& Stock), 2017.

35 Myšlenku scientia potentia est Bacon nejednou opakuje ve svých dobově revolučních úvahách, které specifickým způsobem inspirovaly i našeho Komenského. Viz např. Francis BACON, Nové organon, Svoboda: Praha, 1974, s. 89, 186.

36 Zygmunt BAUMAN, Individualizovaná společnost, Praha: Mladá fronta, 2004, s. 159.

37 Jan SOKOL, Filosofická antropologie. Člověk jako osoba, Praha: Portál, 2002, s. 15-16. 
Dalším problémem moderní metanarace, který přispěl k jejímu rozkladu, byl sklon totalizovat se, tj. činit se exkluzivním výkladem skutečnosti a nástrojem moci. Dobře to popsal M. Foucault, který si povšiml, jak moderní vědecký diskurz bývá užíván jako prostř̌edek všepronikající nadvlády a dozoru. ${ }^{38}$ Forma mocnářské totality se může měnit, ale podstata zůstává. Tak byl pod záštitou velkých př́iběhů legitimizován nejeden totalitní zločin - at už ten kolonialistický na západě, či komunistický na východě. A. Finkielkraut si k tomu všímá, že z hlediska západního tzv. civilizování znamenalo „dělat ze svých současných podmínek vzor, ze svých zvláštních zvyklostí universální schopnosti, ze svých hodnot absolutní kritéria posuzování a z Evropana pána a vlastníka prrírody, nejzajímavější bytost stvoření. [...] Protože Evropa ztělesňovala vůči jiným lidským společnostem pokrok, zdála se kolonizace prostředkem zároveň nejrychlejším i nejušlechtilejším, jak uvést opozdilce na dráhu civilizace. Rozvinutým národům připadalo poslání: urychlit cestu Neevropanů ke vzdělání a blahobytu. Bylo třeba, právě pro blaho primitivních národů, pohltit jejich odlišnost tj. jejich zaostalost - $\mathrm{v}$ západní universálnosti ${ }^{\text {“39. }}$

Konkrétní důsledky totalitního diskurzu, který ovládl tzv. východní blok, důvěrně znají všichni, kdo žili pod komunistickým režimem. I ten disponoval velkým př́iběhem o třídním boji, který připomeňme - měl eschatologicky vyústit $\mathrm{v}$ zaslíbený ráj na zemi v podobě beztřídní společnosti. Rozpad těchto metanarativních záštit způsobil, že všechny jednoduché orientační body a vzorce, díky kterým moderní svět působil solidně a které usnadňovaly volby životních strategií, se rozplynuly. Nastupující generace, odkojená postmoderním mlékem, již nevnímá realitu jako soudržný koherentní celek, ve kterém by bylo možné najít nějaký smysluplný systém či logiku, ale spíše jako skrumáž nahodilých a proměnlivých událostí. Pravda je prázdný pojem, se kterým může kdokoli nakládat jakkoli. Objektivní poznání je irelevantní. Právo a spravedlnost bylo vydáno napospas démonu interpretace. A co se vyhlídek do budoucnosti týče, postmoderní generace nevěří, že by jakékoli vědecké, hospodářské, ekonomické, natož pak politické řešení zajistilo lepší existenci, než jaká byla jejich rodičů. Pokrok lidstva je pro postmoderního člověka nadobro ztracená romantická iluze. ${ }^{40}$ Zvláště pak v českém prostředí, kde po celá desetiletí byly velké pravdy ohýbány, napínány a krouceny až do krajnosti a vznosné ideje vulgarizovány nízkými zájmy a kde jeden ideový velkopř́běh střídal druhý, aniž by se dostavoval zaslíbený ráj, upevnil si našinec takřka podmíněný reflex apriorní nedůvěry. Než aby se znovu zklamal, bude radši zklamán předem. Jaké důsledky má tato změna myšlenkového klimatu pro školu a pedagogiku?

$S$ koncem důvěry v meta-narativní instanci škola přišla o své nejcennější jmění. Obrazně řečeno, ztratila svou duši. S velkým př́během ztratila garanta, který by legitimizoval její výchovně-formativní roli ve společnosti. Post-moderní „klient“ již od školy nečeká velké objektivní (světa) názory, definitivní výpovědi či všeobecně platné hodnoty, natož pak nějaké výchovné „obrábění ve jménu univerzálních pravd. Vše, co chce a potřebuje, je pragmatická využitelnost školských produktů. Nevychovávejte mě, co je vám do mě, dejte mi fakta, dovednosti, kompetence, naložím si s nimi, jak budu chtít. Potřebuji být konkurence-schopný, uplatnit se na trhu práce. ${ }^{41}$ Vzdělání se stalo zbožím. Poslední cíl výchovy a vzdělávání je ekonomický. ${ }^{42}$

Taková je poptávka neoliberálního paradigmatu, který se velmi ochotně chopil uprázdněného prostoru po ztracené metanaraci a kterému je škola nucena vyhovět. Škola je tak zredukována

38 Michel FOUCAULT, Dohližet a trestat. Kniha o zrodu vězení, Praha: Dauphin, 2000.

39 Alain FINKIELKRAUT, Destrukce myšlení, Atlantis: Brno, 1993, s. 42.

40 Srov. Zygmunt BAUMAN, Individualizovaná společnost, Praha: Mladá fronta, 2004; Millard J. ERICKSON, Truth or Consequences: the Promise and Perils of Postmodernism, Downers Grove, IL: InterVarsity Press, 2001.

41 „Klientem“ je v této souvislosti především vysokoškolský student, ale prostř̌ednictvím svých rodičů jím může být i žák základní školy.

42 Radim PALOUŠ, Doba postedukační, in: Dary J. Peškové, Rozhovory, které pokračují, ed. Zuzana SVOBODOVÁ - Irena VAŇKOVÁ, Praha: Eurolex Bohemia, 2007. 
do servisní či asistenční pozice individuální samosvojnosti - řečeno pojmem Komenského, nebo sebe-prosazení - řečeno pojmem současným. V postmoderním klimatu se škola stává depozitářem či - bez pejorativnosti řečeno - supermarketem, kam konzument dochází, aby si eklekticky vybíral $\mathrm{z}$ široké nabídky více či méně kličových produktů vhodných $\mathrm{k}$ jeho bezprostřední potřebě. ${ }^{43}$

Teoretici i praktici vzdělávání mluví o „frustraci“a „krizi““ ${ }^{44}$ Přestože bychom se rádi považovali za „společnost věděni“ nebo „vzdělanostní společnost", ve skutečnosti vzdělanost upadá. ${ }^{45}$ Je jakýmsi apendixem, který se musí přizpůsobovat diktátu trhu, nastaveného dle ekonomické reakce na potřebu inovací v přírodních vědách a technologických oborech. Bohem trhu je „zisk“, jeho knězem „efektivita“ a nástrojem „kvalifikovaný specialista“. Edukační produkty tedy musejí být prodejné. Edukační instituce necht̉ se bud' přizpůsobí, stanou se „podnikavé, nebo at zaniknou ${ }^{46}$. Neumíte prodat svou filologii, teologii, filozofii, etiku nebo bohemistiku, nejste tedy k potřebě. Zasáhla nás „postedukační" epidemie? Táže se filozoficky R. Palouš ${ }^{47}$. Stojí vzdělávací sektor „na křižovatce“ a potřebuje „nově definovat svou identitu“? Vede nás k tázání Z. Bauman. ${ }^{48}$

\section{Závěr: Pokrok nebo krize?}

Záměrem tohoto eseje bylo předložit materiál, který má pomoci reflexi současného filozofování o výchově v historicko-filozofických souvislostech. Je zřejmé, že hodnotit edukaci - jakož i jakýkoliv jiný humanitní fenomén - je záležitost veskrze sporná. Která edukační filozofie je dobrá a která špatná, nebo alespoň lepší či horší? Ta pre-moderní, moderní či současná? Zdá se, že záleží na předporozumění a očekávání tazatele. Pokud neočekáváme víc než výbavu ke konkurenceschopnosti, pak bychom mohli být se současným edukačním trendem celkem spokojeni. Aktuální edukační mainstream takový servis zajištuje relativně dobře. Má schopnost produkovat jedince velmi obstojně kvalifikované pro konkrétní specializovaná odvětví. Pokud bychom ovšem od výchovně-vzdělávacího procesu očekávali vedení k lidskosti, ke ctnosti, ke kultivaci duchovních složek osobnosti, pak budeme zklamáni. Postmodernita nezná instanci, která by legitimizovala takové cíle. Vše, co se ve výchově a vzdělávání dělo během posledních několika století, dávalo smysl bud' na pozadí věčnosti, nebo pokroku. Jestliže modernita skoncovala s prvním, postmodernita dala sbohem druhému. Doba premoderní ctila bohy, moderní rozum, postmoderna nectí nic. ${ }^{49}$ Respektive - ctí modlu jménem Zisk. Edukace, která se vydá do služeb tomuto „bohu“, se stává zbožím. ${ }^{50}$ Někdo to vnímá a vítá jako pokrok, jiný jako krizi.

Nechci předstírat akademickou neutralitu, proto na závěr vyslovím svou filozoficko-výchovnou preferenci, ačkoli jsem si jist, že pozornému čtenáři je již od prvních řádků zřejmá. Přimlouvám

43 Tento fenomén dokázal jedinečným způsobem předvídat N. Postman ve svém sociologicky-analytickém bestseleru Neil POSTMAN, Amusing Ourselves to Death: Public Discourse in the Age of Show Business, New York City: Penguin Books, 1986.

44 Literatury pojednávající o „krizovosti“ české pedagogiky je značné množství. Viz např. Jiří HAŠKOVEC, Současná krize české pedagogiky, in: Česká pedagogika: proměny a výzvy: Sborník k životnímu jubileu profesora Jiř́ho Kotáska, ed. Eva WALTEROVÁ, Praha: UK - PedF, 2004; Vladimíra SPILKOVÁ, Pedagogika na Pedagogické fakultě UK - současný stav a perspektivy, in: Česká pedagogika: Proměny a výzvy, ed. Eliška WALTEROVÁ, Praha: Portál, 2004; Jarmila SKALKOVÁ, Humanizace vzdělávání a výchovy jako soudobý pedagogický problém, Ústí nad Labem: UJEP, 1993; Radim PALOUŠ, Heretická škola: o filosofii výchovy ve světověku a Patočkově pedagogice čili filipika proti upadlé škole, Praha: OIKOYMENH, 2008.

45 Viz např. mj. Výzvu všem ,jejichž hlas je slyšet“. Obsah výzvy i se signatáři je volně př́stupný na internetu, viz např. http://ktv.mff.cuni. cz/IFORUM-4389.html, citováno 20. 9. 2018.

46 Jitka LORENZOVÁ, Kontexty vzdělávání v postmoderní situaci, Praha: Humanitas, 2016.

47 Radim PALOUŠ, Doba postedukační, in: Dary J. Peškové, Rozhovory, které pokračují, ed. Zuzana SVOBODOVÁ - Irena VAŇKOVÁ, Praha: Eurolex Bohemia, 2007.

48 Zygmunt BAUMAN, Individualizovaná společnost, Praha: Mladá fronta, 2004, s. 147.

49 BAUMAN, Individualizovaná společnost..., s. 157.

50 Srov. Václav BĚLOHRADSKÝ, Je vzdělání na cestě stát se zbožím?, 2003, (on-line), dostupné na: http://heol.loar.sweb.cz/Vzdelani.html, citováno 19. 11. 2012. 
se za takovou filozofii výchovy, která by rozvíjela slovy Komenského „celého člověka“"51. Ř́kejme tomu třeba holistické, široké, obecné nebo otevřené pojetí edukace. Důvodem, proč usilovat o takové pojetí, není, aby si „i skladník mohl přečíst Vergilia v originálu“. Předkládám dva fundamentální argumenty pro celostní pojetí: 1) Ontologicko-antropologický - vychází z toho, jak je ustrojena lidská bytost, 2) Sociologický - jak je ustrojena lidská společnost.

Pro výklad prvního argumentu nám ještě jednou poslouží Komenský. Jeho slavná triáda „omnes, omnia, omnino“ (všechny, všemu, všestranně) jedinečně vystihuje celostní přístup k edukaci; odpovídá na tři fundamentální edukační otázky: vzdělávat koho, čemu a jak? Vzdělávat a) všechny lidi, b) ve všem, čeho je třeba k dobrému životu, c) všemi vhodnými prostředky. Tedy popořadě: A) Všechny lidi, protože všichni mají povolání rozvinout potenciál svého lidství, každý člověk - chudý, bohatý, urozený, neurozený, muž i žena - je nadán potenciálem ztělesňovat nejvyšší myslitelné dobro ve smyslu Imago Dei. Navíc je lidem dáno pobývat pospolu „na jednom jevišti světa“ a vše, co se tu děje, „všech se týče“, musíme se proto učit brát ohled na druhé i na celek společnosti. Blaho jedince totiž není dlouhodobě udržitelné bez blaha celku. B) Teze, že je třeba vzdělávat ve všem, čeho je třeba k dobrému životu, vychází z antropologického předpokladu, že člověku je dáno být znalým věcí, být mocen věcí, užívat věci náležitě, tj. v souladu s jejich přirozeností. Dobrý život vede ten, kdo ví, co je dobré, chce dobré a koná dobré, a to „i když se nikdo nedívá“. Řečeno současnou terminologií, jde o kultivaci složky kognitivní, volně-morální a duchovní složky výchovy. Komenský ještě k otázce edukačních obsahů říká, že je třeba znát nikoli „mnoho“, ale „mnohé“, tedy mít široký přehled. C) Vhodné prostředky či způsoby opět vychází z Komenského ontologicko-antropologických předpokladů - totiž, že bytí má řád a že tento řád je esenciálně harmonický. „Umělá“ (ve smyslu umná) práce pedagoga spočívá v uvádění člověka (dítěte) do tohoto řádu. To se pochopitelně nemưže a nesmí dít násilnou cestou, a to přesto, že člověk trpí samosvojným sklonem „rušivě vystupovat $z$ řádu bytí, tj. být neřádem. Jde o specifickou a jemnou dovednost či umění nakládat s věcmi (včetně člověka) v souladu s jejich přirozenou povahou, nekřivit je, nečinit násilí jejich podstatě, neužívat je špatně (abusus).

Ve prospěch celostní, široce pojaté filozofie výchovy hovoří dále argument sociologický. Jak již bylo řečeno - logika zisku a prodejnosti vyvolává poptávku po kvalifikaci, resp. po specialistech. Avšak důraz na úzkou specializaci za účelem prodejnosti destabilizuje celek společnosti, a to proto, že kvalifikace činí jedince „použitelným“ jen ve velmi redukovaném spektru lidských situací. Bělohradského výraz převzatý od Konrada Liessmanna ${ }^{52}$ „fachidiot“ (kvalifikovaný idiot) je možná silný, nicméně dobře vystihuje úskalí post-edukační redukce. ${ }^{53}$ Kvalifikace uschopňuje člověka k vykonávání úzce specializované činnosti, ale nedopřává širší vědomostní rozhled, neučí řešit komplexní problémy, neučí myslet v souvislostech, myslet samostatně, nerozvíjí kritické myšlení, nerozvíjí morální kompetence, tvořivost atd. Navíc vede kvalifikační boom k spirálovitému procesu diferenciace společnosti do specializovaných a nezávislých odvětví, z nichž se každé řídí jen vlastními hledisky, sleduje jen své vlastní zájmy a klade odpor každé politické kontrole, tedy ome-

51 Komenského celostní cíle často cituje P. Floss, vynikající filozof a komeniolog. Viz např. Pavel FLOSS, Poselství J. A. Komenského současné Evropě, Brno: Soliton, 2005, s. 26.

52 Konrad LIESSMANN, Teorie nevzdělanosti, Praha: Academia, 2009.

53 Srov. výzva „všem, jejichž hlas je slyšet“, kde se mj. píše: „Na řadě škol jsme svědky soustavného snižování požadavků na znalosti a dovednosti. Ve sdělovacích prostředcích je často zpochybňována role paměti ve vzdělávání, smysl výchovy ke kázni a společenskému chování, důležitost osobního úsilí a význam zodpovědnosti [...] Nedostatečná vzdělanost a malý všeobecný rozhled vede k degradaci populace na nemyslící dav spotřebitelů všeho možného i nemožného, vytváří živnou půdu pro nejrůznější podvodníky, extremisty, je zdrojem ignorance a agresivity vůči lidem i př́rodě.“ (๔ UNIVERZITA KARLOVA, MATEMATICKO-FYZIKÁLNÍ FAKULTA, KATEDRA DIDAKTIKY MATEMATIKY, Všem, jejichž hlas je slyšet, 2007, (on-line), dostupné na: http://kdm.karlin.mff.cuni.cz// akce2/vyzva/vsem.htm, citováno dne 19. 09. 2018). 


\section{9}

zením v zájmu celku. „Neučiní nakonec stále větší moc efektivně jednat, ale ze stále užšího hlediska náš společný svět neobyvatelným - biologicky, psychologicky, sociálně?", táže se Bělohradský. ${ }^{54}$ V podmínkách relativní společenské stability je specializace bezesporu účinná a výhodná, ale v situaci nestability, nejistoty a proměnlivosti, kterou globální kapitalismus stále intenzivněji generuje, se naopak ukazuje potřebné disponovat množstvím „povšechných“, ne úzce zaměřených znalostí, schopností a dovedností, jakkoli se pro trh jeví jako nadbytečné, neužitečné a především neprodejné. „Zajištování redundantních kapacit je nákladné, leží dlouho ladem, a proto je tu vždy riziko, že pod tlakem tržního účtování zisků a ztrát budou zrušeny. Taková účetnická racionalizace ničí ale schopnosti, bez kterých pozdní průmyslová společnost nepřežije, " 55 uzavírám s Bělohradským svou př́mluvu za edukační filozofii, která by se skvěla přívlastky jako otevřená, obecná, celostní či holistická.

\section{Kontakt}

Doc. PhDr. Jan Hábl, Ph.D.

Univerzita Hradec Králové

Pedagogická fakulta

Katedra pedagogiky a psychologie

Rokitanského 62, 50003 Hradec Králové III

jan.habl@uhk.cz

54 Václav BĚLOHRADSKÝ, Je vzdělání na cestě stát se zbožím? (on-line). Dostupné na: http://heol.loar.sweb.cz/Vzdelani.html, citováno dne 19. 11. 2018. 